\title{
Diminished oestrogen sensitivity and increased ovulation rate in adult female rats after prepubertal treatment with oestrogen or pimozide
}

\author{
F. Döcke, W. Rohde, J. Stürzebecher and G. Dörner \\ Institute of Experimental Endocrinology, Humboldt University Medical School (Charité), \\ Schumannstr. 20, 1040 Berlin, G.D.R.
}

\begin{abstract}
Summary. Immature female rats were implanted with oestradiol benzoate or cholesterol in the medial preoptic area at different ages, and the inhibition of the ovariectomy-induced increase of LH secretion by s.c. injected oestradiol was investigated. Medial preoptic oestrogen implants reduced the inhibition of LH secretion in 4-week-old rats, but not in younger animals. Elevation of the circulating oestrogen concentration or suppression of the central nervous dopamine activity by daily injections of oestradiol and pimozide, respectively, from Day 26 to the day of vaginal opening, i.e. during the time when the mechanism of the oestrogen-induced desensitization of the negative oestrogen feedback matures, resulted in considerable diminution of the LH-inhibiting effect of oestradiol in ovariectomized adult females. In intact cyclic rats, both prepubertal treatments led to a significant increase of the average number of eggs per ovulation that was mainly caused by reduction of the number of animals with a low ovulation rate.
\end{abstract}

Keywords: negative oestrogen feedback; oestrogen sensitivity; pimozide; female sexual maturation; ovulation rate; rat

\section{Introduction}

The negative feedback action of oestrogen is essentially involved in the neurohormonal control of the cyclic ovarian function (Karsch et al., 1978). However, in spite of the very effective inhibition of gonadotrophin secretion by oestrogen, the basal circulating LH concentration increases in the face of rising oestrogen concentrations in the blood both prepubertally (rat: Meijs-Roelofs et al., 1983; Döcke et al., 1984a; Urbanski \& Ojeda, 1985; sheep: Foster et al., 1985; cattle: Schams et al., 1981; man: Sizonenko, 1978) and during the preovulatory phase of the ovarian cycle (rat: Fox \& Smith, 1985; sheep: Karsch et al., 1983; cattle: Schams et al., 1977; man: Hoff et al., 1983). The increase of tonic $\mathrm{LH}$ secretion seems to be required for the completion of follicle maturation, occurrence of ovulation, and adequate corpus luteum function (McNatty et al., 1981; Haresign et al., 1983; McNeilly et al., 1984).

A simultaneous rise of circulating oestrogen and basal LH concentrations can only occur if the gonadotrophin-inhibiting effect of oestrogen decreases. This desensitization of the negative oestrogen feedback has been demonstrated in prepubertal rats (Döcke et al., 1984b), sheep (Foster \& Ryan, 1979), pigs (Berardinelli et al., 1984) and heifers (Day et al., 1984) and has also been established in adult rats during the preovulatory phase of the ovarian cycle (Döcke et al., 1984d). Oestrogen itself can induce desensitization to its gonadotrophin-suppressing effect by an action on the medial preoptic area (MPOA): implantation of very low amounts of oestradiol benzoate into the MPOA diminished considerably the inhibition of LH and FSH secretion by s.c. injected oestradiol benzoate in ovariectomized immature (Döcke et al., 1984c) and adult (Döcke et al., 
1984d) female rats, whereas removal of similar oestrogen implants from the MPOA resulted in enhanced sensitivity to the inhibitory effect of oestradiol on $\mathrm{LH}$ release (Döcke et al., 1985). The oestrogen-induced desensitization of the negative oestrogen feedback is probably mediated by suppression of dopamine activity in the MPOA (Döcke et al., 1987) and, possibly, by inhibition of $\beta$-endorphin release from the mediobasal hypothalamus (Stürzebecher et al., 1988).

The present experiments were performed to determine at which stage of post-natal development the mechanism of the oestrogen feedback matures in female rats, and to examine whether alteration of circulating oestrogen concentration or of dopamine activity during this time can influence the sensitivity to oestrogen and ovulation in adulthood.

\section{Materials and Methods}

Animals. Female Wistar rats of a colony strain were reared in the laboratory. They were housed in an air-conditioned room with lights on from 05:00 to 19:00 h. Standard dry pellets and tap water were available ad libitum. Vaginal opening was recorded for some of the rats, and vaginal smears were taken daily from the day of vaginal opening. Ovariectomy was performed under ether anaesthesia between 08:30 and 09:00 h. For s.c. injections, oestradiol benzoate (VEB Jenapharm, Jena, G.D.R.) was dissolved in peanut oil, and the dopamine receptor blocker pimozide (VEB Arzneimittelwerk Dresden, Dresden, G.D.R.) was micro-suspended in a 0.1 M solution of tartaric acid.

The number of ovulated eggs was determined by killing the rats in the morning of the day after oestrus, determined from the vaginal smear patterns. The oviducts were removed, squeezed between two slides and the ova counted under a dissecting microscope.

Implantation of oestradiol benzoate. Implants containing one part oestradiol benzoate to 360 parts cholesterol were prepared by thoroughly mixing both substances for $20 \mathrm{~min}$, heating the powder to just above the melting point and, with continuous stirring, aspirating the mixture into calibrated glass capillary tubes with an inner diameter of $0.2 \mathrm{~mm}$ and an outer diameter of approximately $0.35 \mathrm{~mm}$. After coagulation, the outer surface of the tubes was cleaned with ether under microscopic control to ensure that the substances were limited to the interior of the tubing. One set of implants prepared simultaneously was used throughout the experiment. Similarly prepared cholesterol implants were used for controls.

The rats were anaesthetized with ether and placed in a stereotaxic instrument. After bilateral introduction in the MPOA the capillary tubes were fixed to the skull with dental cement and removed at autopsy.

Assay of serum LH concentrations. Trunk blood was collected at autopsy, which was performed between 13:30 and 14:00 h. Serum LH was measured by an homologous double-antibody radioimmunoassay. NIAMDD Rat LH-I-5 (NIAMDD Rat Pituitary Hormone Distribution Program, NIH, Bethesda, MD, U.S.A.) was radioiodinated with ${ }^{125}$ I (IMS 30; Amersham International plc, Bucks, U.K.) using the chloramine-T method (Greenwood et al., 1963). The labelled hormone was purified by chromatography on a Sephadex-G 50 column and by disc electrophoresis. NIAMDD-A Rat LH-S-5 was used as antibody. The sensitivity of the assay was $1.2 \mathrm{ng} / \mathrm{ml}$, and the intra- and interassay coefficients of variation were $5.4 \%$ and $11 \cdot 1 \%$. All samples were run in duplicate. Results were expressed as ng NIAMDD LH-RP-1/ml.

Evaluation of implantations. The brains of the implanted rats were removed at autopsy and fixed in $10 \%$ formalin. Frozen serial sections $(15 \mu \mathrm{m})$ were cut transversely and stained with haematoxylin and eosin to determine the tracks of the capillary tubes. Rats were only included in the evaluation if the implants were located in the ventral part of the medial preoptic nucleus between A 7020 and A $6670 \mu \mathrm{m}$ by the co-ordinates of König \& Klippel (1963).

Statistical analysis. Results are presented as means \pm s.e.m. (serum LH concentrations) or means \pm s.d. (numbers of eggs). Groups of data were compared using Student's $t$ test for unpaired samples after application of the Fisher test and the $\chi^{2}$ test as a test of goodness of fit.

\section{Results}

\section{Maturation of the mechanism for desensitization of the negative oestrogen feedback}

Immature female rats were bilaterally implanted with oestradiol benzoate or cholesterol in the MPOA at 18, 24 or 31 days of age and ovariectomized in the morning of the 3rd day after implantation. Females of the two younger groups were injected s.c. with $0.05 \mu \mathrm{g}$ oestradiol benzoate $/ 100 \mathrm{~g}$ body weight at 13:00 h on this day. In this strain of rats, spontaneous prepubertal desensitization of the negative oestrogen feedback begins after the 4th week of life (Döcke et al., 1984b), and so 


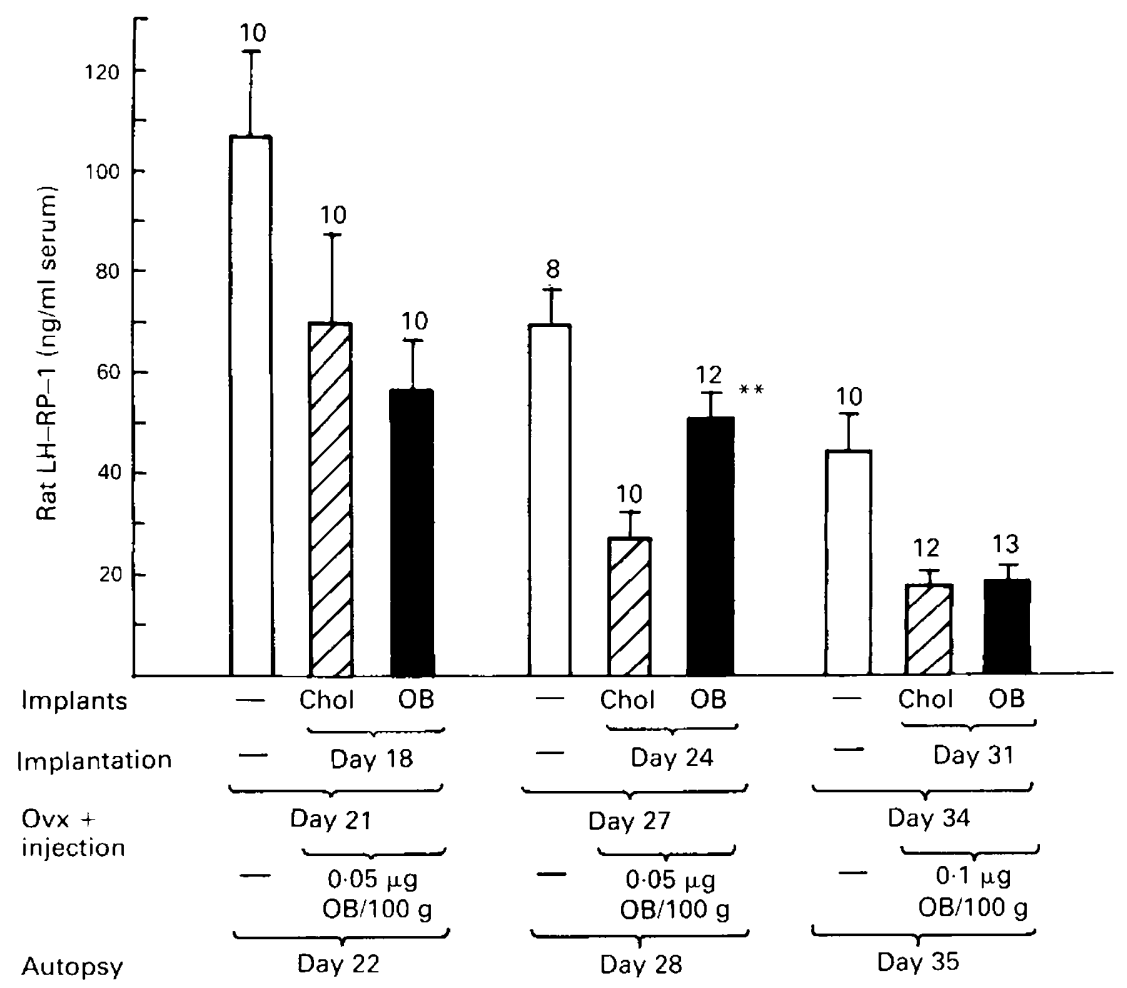

Fig. 1. Maturation of the oestrogen-induced desensitization of the negative oestrogen feedback in immature female rats. The rats were implanted with oestradiol benzoate $(\mathrm{OB})$ or cholesterol (Chol) in the MPOA at different ages and treated as outlined in the figure. Ovx = ovariectomy. Values are means \pm s.e.m. The numbers of rats per group are indicated above each bar. ${ }^{* *} P<0.01$ compared with the corresponding controls implanted with cholesterol.

34-day-old females were injected with $0 \cdot 1 \mu \mathrm{g}$ oestradiol benzoate/100 $\mathrm{g}$ body weight. All rats were autopsied exactly $24 \mathrm{~h}$ after the injection, and the serum LH concentration was estimated.

Figure 1 demonstrates that oestradiol injected on Day 21 suppressed the ovariectomy-induced increase of LH secretion to a similar degree in females implanted in the MPOA with oestradiol benzoate or with cholesterol at 18 days of age. In contrast, implantation of oestradiol on Day 24 resulted in a significant reduction of the LH-inhibiting effect of oestrogen 3 days later as compared to the controls implanted with cholesterol. A desensitizing effect of medial preoptic oestradiol implants was again not demonstrable in the oldest group of rats.

\section{Effect of pretreatment with oestradiol or pimozide on the oestrogen sensitivity in adulthood}

Female rats were injected daily with $0.05 \mu \mathrm{g}$ oestradiol benzoate $/ 100 \mathrm{~g}$ body weight, $0.126 \mathrm{mg}$ pimozide $/ 100 \mathrm{~g}$ body weight or with oil from the 26 th day of age to the day of vaginal opening. Daily vaginal smears were taken after vaginal opening had occurred. The rats were ovariectomized on the day after the first or 10th vaginal oestrus and injected s.c. with $3 \mu \mathrm{g}$ oestradiol benzoate $/ 100 \mathrm{~g}$ body weight or oil at 13:00 h on the 3 rd day after ovariectomy (Fig. 2). Evaluation of the serum LH concentrations $24 \mathrm{~h}$ after the injection revealed that rats treated prepubertally with oestrogen or pimozide did not respond to the administration of oestradiol benzoate, whereas significant inhibition of LH secretion by oestradiol was recorded in females pretreated with oil. 


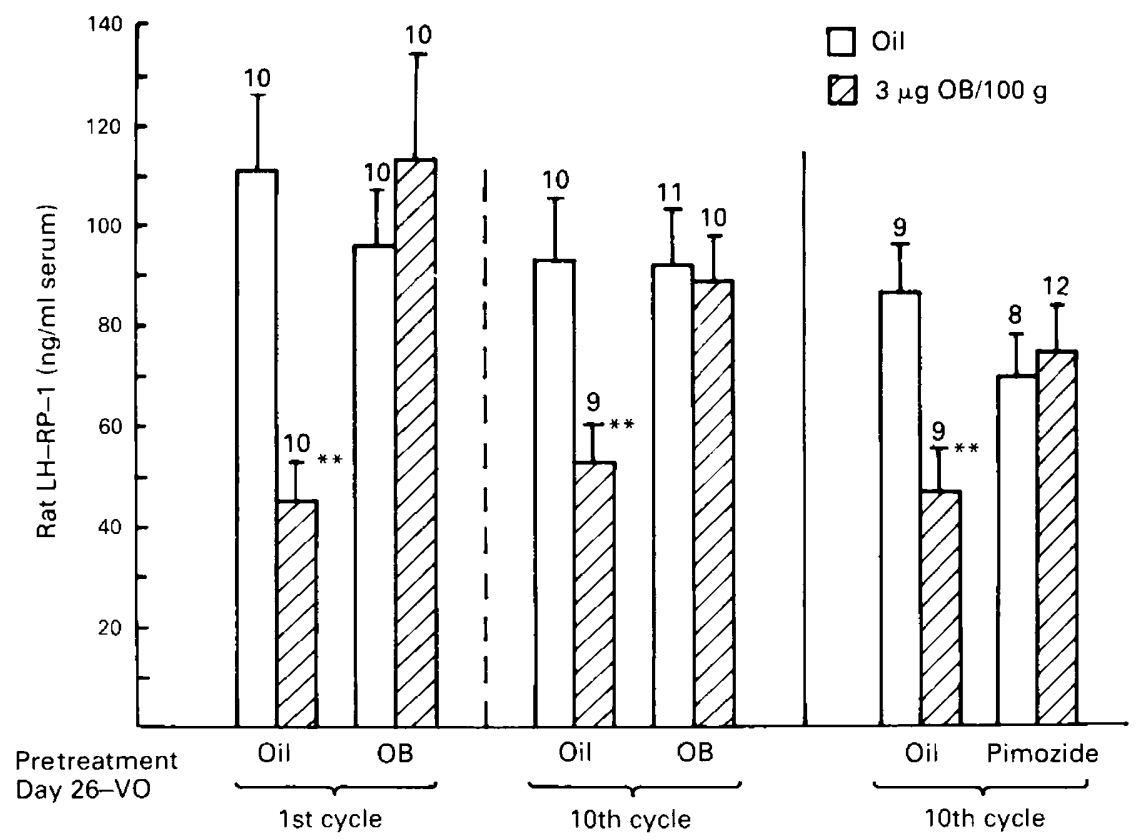

Fig. 2. Effect of prepubertal treatment with oestradiol benzoate (OB) or pimozide on the sensitivity to the LH-inhibiting effect of oestradiol benzoate in adult female rats. $\mathrm{VO}=$ vaginal opening. For details of treatment see text. Values are means \pm s.e.m., and the numbers of rats per group are indicated above each bar. ${ }^{* *} P<0 \cdot 01$ compared with the corresponding controls injected with oil in adulthood.

\section{Effect of pretreatment with oestradiol or pimozide on ovulation}

Groups of rats pretreated prepubertally as in the experiment described above were autopsied on the morning of the day of metoestrus after completion of the 10th vaginal cycle, and the number of ovulated eggs was determined. There were (mean \pm s.d.) $8.7 \pm 1.98,10.3 \pm 1.94$ and $9.8 \pm 1.60$ eggs in 29 females pretreated with oil, 38 rats injected with oestradiol benzoate and 22 rats pretreated with pimozide, respectively $(P<0.01$ and $P<0.05$ as compared with the controls pretreated with oil). An additional group of 19 females injected prepubertally with oestradiol benzoate was killed after the 5 th vaginal cycle. In these rats $10 \cdot 4 \pm 1 \cdot 71$ eggs were found.

The frequency distributions of the numbers of eggs per ovulation in rats autopsied after the 10th vaginal cycle are summarized in Fig. 3. The high frequency of ovulations yielding less than 10 ova as recorded in the controls was clearly reduced after pretreatment with oestradiol or with pimozide. Moreover, although the distribution of ovulations in the control group differed significant from a normal distribution $(P<0.001)$, this was not the case in either experimental group $(P>0 \cdot 10)$.

\section{Discussion}

Döcke et al. (1984c) have shown that immature female rats implanted in the MPOA with small amounts of oestradiol benzoate at 24 days of age exhibited precocious prepubertal desensitization to the LH- and FSH-inhibiting effects of oestrogen around Day 30. In accordance with this finding, the present results suggest that the mechanism of the oestrogen-induced desensitization of the negative oestrogen feedback begins to mature in female rats during the 4 th week of post-natal life. 


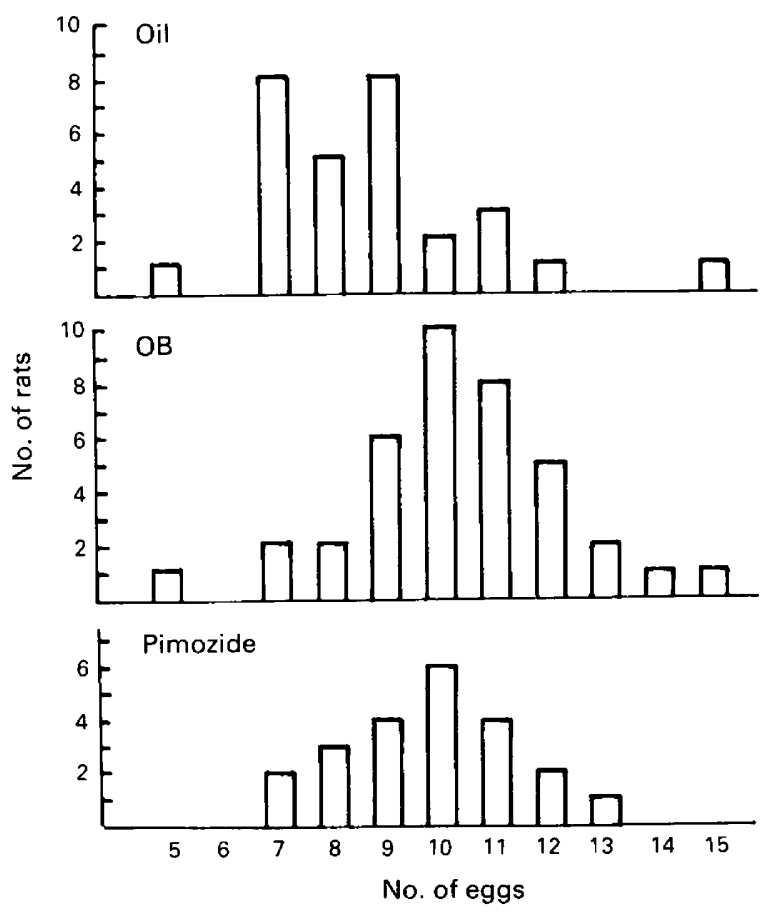

Fig. 3. Effect of prepubertal treatment with oestradiol benzoate (OB) or pimozide from Day 26 to the day of vaginal opening on the frequency distribution of the numbers of eggs per rat recorded at the 10th post-pubertal ovulation. The differences between the controls injected prepubertally with oil and the rats pretreated with oestradiol or with pimozide are significant $(P<0.001$; test of goodness of fit).

The inhibition of LH secretion by oestradiol injected on Day 21 was not reduced by implants of oestradiol benzoate placed in the MPOA on Day 18, but implantation on Day 24 resulted in significant diminution of the oestrogen-induced suppression of LH release on Day 28.

During the 5th week of life, the animals again did not respond to the medial preoptic implantation of oestradiol benzoate. This was probably due to the spontaneous prepubertal desensitization of the negative oestrogen feedback that occurs in the strain of rats used at this time (Döcke et al., 1984b). This assumption is supported by findings which showed that bilateral lesions of the MPOA lead to considerable diminution of the oestrogen sensitivity in 29-day-old females (Döcke et al., 1984c), but not in rats approaching the onset of puberty (unpublished data).

Further experiments demonstrated that elevation of the circulating oestrogen concentration or inhibition of the central nervous dopamine activity from Day 26 to the day of vaginal opening, i.e. during maturation of the oestrogen-induced desensitization of the negative oestrogen feedback, reduced markedly the oestrogen sensitivity in adulthood. The LH response to an injection of oestradiol benzoate or oil was examined 3 days after ovariectomy of adult cyclic rats because, under these conditions, the influence of ovarian oestrogen secretion on the efficacy of the negative oestrogen feedback has apparently declined and constantly high oestrogen sensitivity is recorded throughout the ovarian cycle (Döcke et al., 1985).

Long-lasting diminution of the gonadotrophin-inhibiting effect of oestrogen following elevation of the prepubertal circulating oestrogen concentration may also occur in humans. Apter \& Vihko (1985) recorded higher prepubertal serum oestradiol concentrations in girls with early menarche than in those exhibiting menarche at later ages. In the former girls, who also showed 
earlier onset of ovarian cycles, significantly increased circulating oestrogen concentrations, suggesting desensitization of the negative oestrogen feedback, were found up to at least 17-25 years of age (Vihko \& Apter, 1984).

Döcke et al. (1987) have concluded that oestrogen may induce desensitization to its negative feedback action in prepubertal and adult female rats by suppressing dopamine activity in the MPOA which belongs to the incerto-hypothalamic dopamine system (Björklund et al., 1975). The equivalent responses obtained in the present study after prepubertal treatment with oestradiol benzoate or with pimozide, which inhibits the dopamine neurotransmission by blocking the dopamine receptors (Seeman, 1981), support this assumption.

Reduced sensitivity of the negative oestrogen feedback should result in improvement of the ovulation rate, because more ovarian follicles can develop and the serum oestrogen concentration can increase to a higher level without suppressing the tonic gonadotrophin secretion and arresting the final maturation of ovarian follicles. This hypothesis could be confirmed. A significant increase of the mean number of eggs per ovulation was found after prepubertal administration of both oestradiol benzoate and pimozide. This effect appeared to depend primarily upon reduction of the number of ovulations yielding fewer than 10 eggs and not on further augmentation of the ovulatory reaction in rats with a spontaneously high ovulation rate (Fig. 3). In this way, normal distribution of the numbers of eggs was achieved with a maximum at 10 ova per rat.

Numerous studies have been performed to increase the ovulation rate in farm animals. Promising results have been reported after active immunization of ewes against androstenedione (Scaramuzzi et al., 1977; Cox et al., 1982), testosterone (Scaramuzzi et al., 1981; Cox et al., 1982) or bovine follicular fluid (Cummins et al., 1986), which are probably also due to diminution of the inhibition of tonic gonadotrophin secretion (Martensz \& Scaramuzzi, 1979; Cummins et al., 1986). Attempts to induce similar effects in heifers have been only partly successful (Wise \& Schanbacher, 1983; Price et al., 1987a, b). The present findings point to the possibility that increased ovulation rates may be obtained by prepubertal treatment with oestrogen or dopamine antagonists. They also suggest that this method may be suitable to increase the average number of ovulations in polyovulatory species such as the pig by improving the ovulation rate in animals with low prolificacy.

We thank the National Institute of Arthritis, Metabolism and Digestive Diseases, U.S.A., for the generous gift of LH for iodination, LH antiserum, and assay standard; and Mrs U. Schramme and Mrs R. Zillmann for skilful technical assistance.

\section{References}

Apter, D. \& Vihko, R. (1985) Early menarche, a risk factor for breast cancer, indicates early onset of ovulatory cycles. J. clin. Endocr. Metab. 57, 82-86.

Berardinelli, J.G., Ford, J.J., Christenson, R.K. \& Anderson, L.L. (1984) Luteinizing hormone secretion in ovariectomized gilts: effects of age, reproductive stage and estrogen replacement. J. Anim. Sci. 58, $165-173$.

Björklund, A., Lindvall, O. \& Nobin, A. (1975) Evidence of an incerto-hypothalamic dopamine neuron system in the rat. Brain Res. 89, 29-42.

Cox, R.I., Wilson, P.A., Scaramuzzi, R.J., Hoskinson, R.M., George, J.M. \& Bindon, B.M. (1982) The active immunization of sheep against oestrone, androstenedione or testosterone to increase twinning. Proc. Aust. Soc. Anim. Prod. 14, 511-514.

Cummins, L.J., O'Shea, T., Al-Obaidi, S.A.R., Bindon, B.M. \& Findlay, J.K. (1986) Increase in ovulation rate after immunization of Merino ewes with a fraction of bovine follicular fluid containing inhibin activity. J. Reprod. Fert. 77, 365-372.

Day, M.L., Imakawa, K., Garcia-Winder, M., Zalesky, D.D., Schanbacher, B.D., Kittok, R.J. \& Kinder, J.E. (1984) Endocrine mechanisms of puberty in heifers: estradiol negative feedback regulation of luteinizing hormone secretion. Biol. Reprod. 31, 332-341.

Döcke, F., Rohde, W., Stahl, F., Smollich, A. \& Dörner, G. (1984a) Serum levels of FSH, LH and estradiol$17 \beta$ in female rats around the time of puberty onset. Exp. clin. Endocrinol. 83, 6-13.

Döcke, F., Rohde, W., Gerber, P. \& Dörner, G. (1984b) Evidence that desensitization to the negative estrogen feedback is a prepubertal and not a postpubertal event in female rats. Exp. clin. Endocrinol. 84, 1-6.

Döcke, F., Rohde, W., Gerber, P. \& Kreuz, G. (1984c) Medial preoptic area, estrogen, and the peripubertal 
desensitization to the negative estrogen feedback in female rats. Neuroendocrinology 39, 74-80.

Döcke, F., Rohde, W., Gerber, P., Chaoui, R. \& Dörner, G. (1984d) Varying sensitivity to the negative oestrogen feedback during the ovarian cycle of female rats: evidence for the involvement of oestrogen and the medial preoptic area. J. Endocr. 102, 287-294.

Döcke, F., Rohde, W., Stahl, F., Chaoui, R. \& Dörner G. (1985) Postovulatory sensitization to the negative oestrogen feedback in female rats is probably induced by the preceding decline of the oestrogen concentration in the medial preoptic area. Exp. clin. Endocrinol. 86, 171-177.

Döcke, F., Rohde, W., Oelssner, W., Schleussner, E., Gutenschwager, I. \& Dörner, G. (1987) Influence of the medial preoptic dopaminergic activity on the efficiency of the negative estrogen feedback in prepubertal and cyclic female rats. Neuroendocrinology 46, 445-452.

Foster, D.L. \& Ryan, K.D. (1979) Endocrine mechanisms governing transition into adulthood: a marked decrease in inhibitory feedback action of estradiol on tonic secretion of luteinizing hormone in the lamb during puberty. Endocrinology 105, 896-904.

Foster, D.L., Yellon, S.M. \& Olster, D.H. (1985) Internal and external determinants of the timing of puberty in the female. J. Reprod. Fert. 75, 327-344.

Fox, S.R. \& Smith, M.S. (1985) Changes in the pulsatile pattern of luteinizing hormone secretion during the rat estrous cycle. Endocrinology 116, 1485-1492.

Greenwood, F.C., Hunter, W.M. \& Glover, J.S. (1963) The preparation of ${ }^{131} \mathrm{I}$-labelled human growth hormone of high specific radioactivity. Biochem. J. 89, 114-123.

Haresign, W., Foxcroft, G.R. \& Lamming, G.E. (1983) Control of ovulation in farm animals. J. Reprod. Fert. 69, 383-395.

Hoff, J.D., Quigley, M.E. \& Yen, S.S.C. (1983) Hormonal dynamics at midcycle: a reevaluation. J. clin. Endocr. Metab. 57, 792-796.

Karsch, F.J., Legan, S.J., Ryan, K.D. \& Foster, D.L. (1978) The feedback effects of ovarian steroids on gonadotrophin secretion. In Control of Ovulation, pp. 29 48. Eds D. B. Crighton, N. B. Haynes, G. R. Foxcroft \& G. E. Lamming. Butterworths, London.

Karsch, F.J., Foster, D.L., Bittman, E.L. \& Goodman, R.L. (1983) A role for estradiol in enhancing luteinizing hormone pulse frequency during the follicular phase of the estrous cycle of the sheep. Endocrinology 113, 1333-1339.

König, J.F.R. \& Klippel, R.A. (1963) The Rat Brain. A Stereotaxic Atlas of the Forebrain and Lower Parts of the Brainstem. Williams \& Wilkins, Baltimore.

Martensz, N.D. \& Scaramuzzi, R.J. (1979) Plasma concentrations of luteinizing hormone, folliclestimulating hormone and progesterone during the breeding season in ewes immunized against androstenedione or testosterone. J. Endocr. 81, 249-259.

McNatty, K.P., Gibb, M., Dobson, C. \& Thurley, D.C. (1981) Evidence that changes in luteinizing hormone secretion regulate the growth of the preovulatory follicle in the ewe. J. Endocr. 90, 375-389.

McNeilly, A.S., Fraser, H.M. \& Baird, D.T. (1984) Effect of immunoneutralization of $\mathrm{LH}$ releasing hormone on LH, FSH and ovarian steroid secretion in the preovulatory phase of the oestrous cycle in the ewe. $J$. Endocr. 101, 213-219.

Meijs-Roelofs, H.M.A., Kramer, P. \& Sander, H.J. (1983) Changes in serum concentration of luteinizing hormone in the female rat approaching puberty. $J$. Endocr. 98, 241-249.

Price, C.A., Morris, B.A. \& Webb, R. (1987a) Reproductive and endocrine effects of active immunization against a testosterone conjugate in the heifer. $J$. Reprod. Fert. 81, 149-160.

Price, C.A., Morris, B.A., O'Shea, T. \& Webb, R. (1987b) Active immunization of cattle against partly purified follicular fluid from sheep. J. Reprod. Fert. 81, I6I-168.

Scaramuzzi, R.J., Davidson, W.G. \& Van Look, P.F.A. (1977) Increasing the ovulation rate of sheep by active immunization against an ovarian steroid, androstenedione. Nature, Lond. 269, 817-818.

Scaramuzzi, R.J., Baird, D.T., Martensz, N.D., Turnbull, K.E. \& Van Look, P.F.A. (1981) Ovarian function in the ewe after active immunization against testosterone. J. Reprod. Fert. 61, 1-9.

Schams, D., Schallenberger, E., Hoffman, B. \& Karg, H. (1977) The oestrous cycle of the cow: hormonal parameters and time relationships concerning oestrus, ovulation, and electrical resistance of the vaginal mucus. Acta endocr., Copenh. 86, 180-192.

Schams, D., Schallenberger, E., Gombe, S. \& Karg, H. (1981) Endocrine patterns associated with puberty in male and female cattle. J. Reprod. Fert., Suppl. 30, $103-110$.

Seeman, P. (1981) Brain dopamine receptors. Pharmac. Rev. 32, 229-312.

Sizonenko, P.C. (1978) Endocrinology in preadolescents and adolescents. I. Hormonal changes during normal puberty. Am. J. Dis. Childh. 132, 704-712.

Stürzebecher, J., Döcke, F., Rohde, W. \& Dörner, G. (1988) Effect of medial preoptic oestradiol implants on hypothalamic $\beta$-endorphin concentration. Exp. clin. Endocrinol. 91 (in press).

Urbanski, H.F. \& Ojeda, S.R. (1985) The juvenileperipubertal transition period in the female rat: establishment of a diurnal pattern of pulsatile luteinizing hormone secretion. Endocrinology 117 , 644649.

Vihko, R. \& Apter, D. (1984) Endocrine characteristics of adolescent menstrual cycles: impact of early menarche. J. Steroid. Biochem. 20, 231-236.

Wise, T.H. \& Schanbacher, B.D. (1983) Reproductive effects of immunizing heifers against androstenedione and oestradiol-17ß. J. Reprod. Fert. 69, $605-612$.

Received 2 November 1987 